\title{
НАВЧАННЯ ДРУГОЇ ІНОЗЕМНОЇ МОВИ В СТАРШІЙ ШКОЛІ ЧЕСЬКОЇ РЕСПУБЛІКИ: ЛІНГВОДИДАКТИЧНІ ПРИНЦИПИ ТА ТИПИ МОВНОЇ ІНТЕРФЕРЕНЦІї
}

\author{
ЮЛІЯ ТАЛАЛАЙ \\ Дрогобицький державний педагогічний університет імені Івана Франка, \\ Дрогобич - Україна \\ utal@ukr.net \\ NAUCZANIE DRUGIEGO JEZZYKA OBCEGO W GIMNAZJUM W CZECHACH: \\ ZASADY LINGWODYDAKTYCZNE ORAZ TYPY INTERFERENCJI JĘZYKOWEJ

\section{JULIA TAŁAŁAJ} \\ Państwowy Uniwersytet Pedagogiczny imienia Iwana Franki w Drohobyczu, \\ Drohobycz - Ukraina
}

STRESZCZENIE. W artykule dokonano analizy lingwodydaktycznych zasad nauczania drugiego języka obcego w gimnazjum w Czechach. Język angielski postrzegany jest jako pierwszy język obcy. Przeprowadzono analizę rodzajów interferencji językowych. Wyróżniono pewne struktury gramatyczne, szereg wyrazów w języku angielskim i niemieckim. Określono wpływ języka ojczystego na proces uczenia się drugiego języka obcego.

\section{TEACHING THE SECOND FOREIGN LANGUAGE AT SENIOUR SCHOOL IN THE CZECH REPUBLIC: LINGUO-DIDACTIC PRINCIPLES AND TYPES OF LANGUAGE INTERFERANCE

\author{
YULIA TALALAY \\ Drohobych Ivan Franko State Pedagogical University, Drohobych - Ukraine
}

ABSTRACT. The article deals with the analysis of the linguo-didactic principles of teaching German as the second foreign language in senior schools in the Czech Republic. English has been considered as the first foreign language. The types of the language interference have been analyzed; certain grammar structures, word order in English and German have been singled out; the influence of the native language on the process of learning the second foreign language has been analyzed as well.

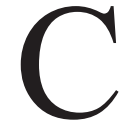

Уучасні інтеграційні процеси й активізація взаємодії країн в умовах відкритого й цілісного світу сприяють упровадженню іноземних мов пілге в освітні пріоритети, обов язковий компетентнісний складник модел народного співробітництва, посиленння уваги й соціальної значущості іноземних мов, процеси міграції населення також стимулюють розвиток іншомовної освіти.

У XXI столітті вивчення іноземної мови зазнає істотних змін. Багатомовність на європейському рівні є однією з вимог часу. Кожен європеєць повинен опанувати дві іноземні мови. У березні 2002 року на засіданні країн-членів Європейського Союзу в Барселоні глави держав і урядів дійшли спільного вис- 
новку, зазначивши таке: „Діти, починаючи з раннього віку, повинні вивчати принаймні дві іноземні мови"'. Упродовж останніх десятиліть мультилінгвізм у країнах-членах $\mathrm{CC}$ перетворився з явища лінгвістичного в основний принцип організації мовної політики сучасної багатомовної і багатонаціональної Європи, що може слугувати орієнтиром у процесі розвитку сучасної вітчизняної системи навчання іноземних мов, зокрема й на рівні старшої школи.

Мета освітньої мовної політики в країнах-членах $Є С$ полягає у володінні громадянами двома іноземними мовами. Англійська мова набирає значущості як лінгва франка, адже в більшості країн Європи вже вважається першою іноземною мовою. Німецька та інші іноземні мови посідають абсолютно нові позиції, обіймаючи друге місце після англійської. У переважній більшості випадків у початкових школах не лише Чеської Республіки, а й в інших країнахчленах $€ \mathrm{C}$, німецьку вивчають як другу іноземну мову. Знання англійської мови допомагає учням у процесі засвоєння лексики, граматики німецької мови.

Дослідженню шкільної іншомовної освіти в країнах-членах Ради Свропи присвячені праці М. Тадеєвої․․ Проблему раннього навчання іноземних мов у Чеській Республіці досліджував О. Пукас 3 ; білінгвізм як мовне та соціальне явище студіювали Т. Боднарчук ${ }^{4}$, Л. Зайцева ${ }^{5}$, Є. Мацнєва ${ }^{6}$, Н. Нікольська ${ }^{7}$. Незважаючи на значну кількість праць, у яких висвітлені питання іншомовної підготовки учнів у Чеській Республіці, на сьогодні відсутні напрацювання щодо іншомовної підготовки старшокласників в умовах мультилінгвізму.

Мета цієї статті - схарактеризувати типи мовної інтерференції та лінгводидактичні принципи навчання німецької мови після англійської учнів старших класів в умовах мультилінгвізму в Чеській Республіці.

Англійська та німецька мови, як відомо, належать до західногерманської гілки індоєвропейської мовної сім'ї. 3 огляду на морфологічну структуру, ці мови відрізняються: німецька належить до флективного типу, англійська аналітичного. Чеські педагоги-методисти В. Янікова ${ }^{8}$, П. Брезінова ${ }^{9}$ одностайно вказують на факт впливу англійської мови на німецьку, а саме: під час вивчення німецької як другої іноземної після англійської мови. В. Янікова вважає, що „під час вивчення німецької мови після англійської чеські учні припускаються інтерференційних помилок. Інстинктивно учень починає використовувати інші види стратегій, наприклад, стратегію плану. Учні також часто використовують компенсаційну стратегію". ${ }^{10}$ На думку чеської дослідниці П. Брезіновоїі ${ }^{11}$, інтернаціоналізми, англіцизми та американізми відіграють важливу роль

${ }^{1}$ Див. про це докл.: ,Education and training”, [в:] Електронний ресурс: http://www.ec.europa. eu/education/languages/pdf/com/2008_0566_cs.pdf (05.02.2017).

2 Див.: М. І. Та де $є$ в а, Сучасні тенденції розвитку шкільної іншомовної освіти в країнахчленах Ради Свропи: порівняльний аналіз, Луганськ 2012.

${ }^{3}$ Див.: О.А.Пукас, Ранне навчання іноземних мов в Чехії, Київ 2013.

${ }^{4}$ Див.: Т. В. Боднарчук, Моделі білінгвальної освіти у досвіді діяльності сучасної школи, Львів 2007.

5 Див.: Л. С. Зайцев в, Білінгвізм як мовне та соиіальне явище, [в:] Електронний реcypc: http://www.rusnauka.com/6_NITSB_2010/Philologia/59619.doc.htm (05.02.2017).

${ }^{6}$ Див.: Є. А. Мацн є в а, Понятття білінгвізму в ряду суміжних понять, Донецьк 2012.

7 Див.: Н. В. Нікольська, Білінгвізм як педагогічна проблема в Свропі, США та Канаді, Донецьк 2012.

${ }^{8} \mathrm{~V}$. J a n i k ov a, Autonomni ućeni a lexikálni strategie pŕi osvojováni cizich jazyku, Brno 2007.

${ }_{9}^{9}$ P. Brezinova, Mnohojazyćnost - vyzva pro vyuku cizich jazyku v 2I. Stoleti, Ceské Budéjovice 2006.

${ }^{10} \mathrm{~V}$. J a n ikova, ibidem, c. 62.

11 P. Brezinova, ibidem, c. 68 . 
Навчання другої іноземної мови в старшій школі Чеської Республіки: лінгводидактичні принциипи та типи мовної інтерференції

у процесі вивчення німецької мови, сприяють кращому засвоєнню лексичного матеріалу та розширюють лексичний вокабуляр. Як зауважує П. Брезінова, засвоєння основних мовних навичок і лексики англійської мови полегшує процес вивчення німецької мови.

Звернімо увагу на слова (фальшиві друзі перекладача — faux amis), що мають однаковий правопис, але різняться за значенням, напр.: to become (англ.) bekommen (нім.), to build (англ.) — bilden, bauen (нім.), speck (англ.) — der Speck (нім.). Спільний словниковий запас (інтернаціоналізми, англіцизми та американізми) можна 3 успіхом використовувати під час навчання німецької мови за умови, що учні систематично працюватимуть із цим лексичним матеріалом. Учнів потрібно навчити ефективно використовувати знання англійської мови та шукати безперервний зв'язок між мовами. У процесі навчання другої іноземної мови важливим завданням постає свідоме порівняння двох іноземних мов, зокрема й участі рідної мови. Хоч очевидно, що англійська й німецька мови мають багато спільного, слід звертати увагу на істотні відмінності між цими мовами, напр., вимова, правопис, наголос, рід іменника, артиклі тощо.

Із точки зору морфології та синтаксису має місце негативний вплив англійської мови на німецьку під час вивчення німецької як другої іноземної. Існує велика вірогідність того, що учень використовуватиме граматичні структури першої іноземної мови в другій іноземній, напр., перенесення синтаксичних структур англійської мови в німецьку. Це може спричинити помилкову інтерференцію однієї іноземної мови в іншу.

Чеський мовознавець Ю. Юхаш під мовною інтерференцією розуміє „порушення мовних норм, що виникли внаслідок впливу інших мовних елементів" (пер. авторський - Ю. Т.) ${ }^{12}$. Зазначений дослідник виокремлює три типи інтерференцій:

1. Екстралінгвальну (між мовами).

2. Інтралінгвальну (у межах однієї мови).

3. Комбіновану.

Інтралінгвальна інтерференція може відбуватися під впливом рідної мови на іноземну, напр.:

1. Ich verabschiede mich mit dir (нім.) / loučim se s tebou (чешс.) / я прощаюся $з$ тобою.

2. Ich verabschiede mich von dir - правильний варіант німецькою мовою.

У першому реченні спостерігаємо помилкове використання прийменника mit у німецькій мові, що мотивоване впливом чеської (рідної) мови. Під час вивчення іноземної мови (напр., німецької) чехами спостерігаємо факт накладання елементів іноземної мови (німецької) на рідну мову (чеську) також, а саме: використання лексичних одиниць німецької мови в чеській (L1 i L2), напр.: tschus (нім.) - tschü̈s (чес.). Під час вивчення німецької мови після англійської спостерігаємо також інтерференцію між двома іноземними мовами (L2 i L3), напр., використання граматичних структур (модальне дієслово + інфінітив) англійської мови в німецькій:

I. Can+Infinitive (англ.), Können+Infinitiv (нім.), напр.:

1. We can stay a few more minutes here (англ.).

2. Wir können bleiben noch ein paar Minuten hier (нім.). - неправильний варіант німецькою мовою.

3. Wir können hier noch ein paar Minuten bleiben - правильний варіант німецькою мовою.

\footnotetext{
${ }^{12}$ J. J u há s z, Probleme der Intereferenz, München 1970, s. 9.
} 
II. Can+Infinitive (англ.), Können+Infinitiv (нім.), напр.:

1. My brother can play football well (англ.).

2. Mein Bruder kann spielen gut Fußball (нім.). - неправильний варіант німецькою мовою.

3. Mein Bruder kann gut Fußball spielen - правильний варіант німецькою мовою.

III. Must + Infinitive (англ.), Müssen + Infinitiv (нім.), напр.:

1. We must help old people (англ.).

2. Wir müssen helfen alten Leuten (нім.) - неправильний варіант німецькою мовою.

3. Wir müssen alten Leuten helfen (нім.) - правильний варіант німецькою мовою.

Інтралінгвальна інтерференція може виникати як у рідній, так і в іноземній мові, напр.: Ich habe geschriebt - ich habe gelernt (нім.) Правильний варіант німецькою мовою: Ich habe geschrieben (haben+Partizip II). Чеські учні помилково використовують форму geschreibt (дієприкметник минулого часу geschrieben) за аналогією з формою дієприкметника минулого часу gelernt.

Англійський лінгвіст С. Джеймс ${ }^{13}$ виокремлює так звану backlash інтерференцію, коли іноземна мова (L2 або L3) впливає на рідну. Унаслідок цього впливу в рідній мові відбувається процес запозичення нових слів, напр.: англійські слова запозичені чеською мовою — cool, OK, oops, ouch, kids, sorry, super, wow, upgraden та ін. Важливим $\epsilon$ те, що це явище $\epsilon$ „соціальним феноменом” 14 .

Очевидним є вплив англійської мови на німецьку в царині семантики. На думку чеських науковців (П. Спіропойлоу, Б. Хуфейзенова), англійська мова виконує роль помічника під час вивчення німецької, полегшує розуміння текстів як у письмовій, так і в усній формах, сприяє плинності мовлення під час спілкування німецькою мовою. У цьому разі спостерігаємо інтерференцію лексикосемантичних елементів:

а) використання тотожних слів, напр.: arm, bitter, instrument, form, hobby, test, tolerant (англ.), der Arm, bitter, der Instrument, die Form, das Hobby, der Test, tolerant (нім.);

б) використання схожих за правописом слів:

- слова подібні за звучанням, але різні за правописом, напр.: brown (англ.) — braun (нім.); to begin (англ.) — beginnen (нім.); fish (англ.) — das Fisch (нім.); house (англ.) - das Haus (нім.); price (англ.) — der Preis (нім.) та ін.;

- слова подібні за правописом, але різні за звучанням, напр.: ball, bank, hand, hunger, name, person, radio, to bind, to find, blond (англ.) та ін. - der Ball, die Bank, die Hand, der Hunger, der Name, die Person, das Radio, binden, finden, der/die/das Blonde (нім.) та ін.;

- слова подібні за значенням, але різні за звучанням і правописом, напр.: bed (англ.) - das Bett; before (англ.) - bevor (нім.); class (англ.) - die Klasse (нім.); end (англ.) — das Ende (нім.); family (англ.) - die Familie (нім.); nature (англ.) - die Natur (нім.); number (англ.) — die Nummer (нім.); practical (англ.) praktisch (нім.); temple (англ.) — der Tempel; fiddle (англ.) — die Fiedel (нім.); to pack (англ.) — packen (нім.) та ін.;

- faux amis, так звані “фальшиві друзі перекладача" — слова, однакові за правописом, але різні за значенням, напр.: chef (англ.) - шеф-повар, головний

${ }^{13}$ C. J a me s, Zur Rechtfertigung der Kontrastiven Lingvistik, Frankfurt/Main 1972, s. 30.

${ }^{14} \mathrm{~F}$. Köhler, Zwischensprachliche Intereferenzen. Eine Analyse syntaktischer und semantischer Intereferenzfehler des Deutschen im Russischen, Tübingen 1975, s. 9. 
Навчання другої іноземної мови в старшій школі Чеської Республіки: лінгводидактичні принципи та типи мовної інтерференції

повар; der Chef (нім.) — керівник, начальник; gift (англ.) — подарунок, das Gift (нім.) - отрута та ін.

У німецькій та англійській мовах, звісно, функціонують схожі за звучанням слова, напр.: so [sou] (англ.) — so [zo:] (нім.), also [olsou] (англ.) — also [alzo:] (нім.).

Чеські методисти розробили систему лінгводидактичних принципів навчання німецької після англійської (В. Янікова, ${ }^{15}$ У. Рампілон ${ }^{16}$ ):

1. Порівняння мовних явищ між мовами L1 (рідна мова) - L2 (перша іноземна мова) - L3 (друга іноземна мова). Це порівняння засноване на свідомій активізації загальномовних знань та умінь учнів. Для досконалого засвоєння німецької слід наголосити на відмінностях у порядку слів розповідних і питальних речень у англійській та німецькій мовах, напр.: підмет + допоміжне дісслово + основне дісслово + додаток в англійській мові; підмет + допоміжне дісслово + додаток + основне дісслово в німецькій мові, напр.:

a) She has already bought all the gifts (англ.). - Вона вже купила всі подарунки.

b) Sie hat schon alle Geschenke gekauft (нім.). - Вона вже купила всі подарунки.

У питальних реченнях з модальними дієсловами аналогічний порядок слів: модальне дісслово + підмет + основне дісслово + додаток в англійській мові; модальне дісслово + підмет + додаток + основне дісслово в німецькій мові, напр.:

a) Can you still buy some bread? - Чи не могла б ти ще купити хліба?

b) Kannst du noch Brot kaufen? - Чи не могла б ти ще купити хліба?

2. Свідомий підхід до вибору стратегій навчання. Учитель повинен безперервно спілкуватись з учнями про:

а) результати навчання, напр.: Що ви вивчили?

б) процес навчання, напр.: Як ви навчались?

Розмова з учнями про результати і процес навчання призводить до свідомого вибору стратегій навчання і підготовки до самостійного навчання без допомоги вчителя. Різноманітність стратегій, запропонованих учням, залежить від творчого підходу вчителя до процесу навчання.

3. Смак експерименту з мовою. Учитель повинен створити дружню і творчу атмосферу в класі, домогтися того, щоб учні не боялися висувати різні гіпотези, ідеї німецькою мовою.

4. Виправлення та аналіз помилок. „Учитель повинен надати можливість учневі самостійно виправити помилку під час усного мовлення, отже, бути задіяним, щоб учень міг проаналізувати помилку та віднайти правильний варіант. Право свідомого виправлення помилки $є$ простим способом збільшення мовної грамотності" ${ }^{\prime \prime}$. Самостійне виправлення помилки є важливою пізнавальною стратегією. Учнів треба проінформувати про типи базових помилок (правописні, граматичні, лексичні, синтаксичні), які вони повинні усвідомити. У сучасній лінгводидактиці існують два підходи до пояснення матеріалу з метою уникнення помилок учнями:

а) пояснення вчителя;

б) індуктивна процедура, де правила і висновки учні роблять самі зі своїх помилок.

${ }^{15} \mathrm{~V}$. J anikova, ibidem.

${ }^{16}$ U. R a mpillon, Lernstrategisches Minimalprofil an der Schwelle von L2 zu L3, [in:] B. Hufe i s e n, Mehrsprachigkeitskonzept. Tertiärsprachen. Deutsch nach Englisch, Strasbourg 2003.

${ }^{17}$ K. Klep pin, Fehler und Fehlerkorrektur, München 1998, s. 133. 
Учні можуть скористатися відомим принципом SOS (sammeln - ordnen systematisieren (нім.); збирай - впорядковуй - систематизуй). Процес виявлення помилок, їхня класифікація, заснована на порівнянні подібностей та відмінностей між мовами, сприяє формуванню знань про природу помилки. Цей процес займає багато часу, проте гарантує учням кращу якість знань і ефективне запам'ятовування лексичного матеріалу, граматичних конструкцій.

Отже, до лінгводидактичних принципів навчання другої іноземної мови (німецької після англійської) належать:

а) порівняння мовних явищ між мовами L1 (рідна мова) - L2 (перша іноземна мова) — L3 (друга іноземна мова);

б) свідомий підхід до вибору стратегій навчання;

в) виправлення та аналіз помилок учнями.

Перспективу дослідження вбачаємо в необхідності аналізу методів та підходів до навчання другої іноземної мови в старшій школі в Чеській Республіці та проектування цих принципів на вивчення української мови як другої іноземної. 